\title{
水縄断層西部地域の地溝状構造
}

\author{
九州大学工学部資源工学科* 茂 木 透・江原 幸雄・西島 潤・本山達也
}

\section{A Graben Structure at the Western Part of the Minou Fault, Southwest Japan}

\author{
Tohru Mogi, Sachio Ehara, Jun Nishijima \\ and Tatsuya Motoy ama \\ Department of Mining, Faculty of Engineering, Kyushu University, \\ 6-10-1 Hakozaki Higashi-ku, Fukuoka 812-81, Japan \\ (Received April 21, 1997; Accepted November 10, 1997)
}

\begin{abstract}
The Minou fault is an active fault system and runs through $25 \mathrm{~km}$ long from Kurume City to Ukiha Town, North Kyushu, Southwest Japan. The fault is considered as the source fault of Tsukushi great earthquake that occurred at 679A.D. We carried out geophysical surveys such as gravity, controlled source magnetotelluric and $\gamma$-ray intensity survey, at the western part of the Minou fault to discuss the subsurface structure around the fault. Based on the gravity survey, the conspicuous graben structure was detected as the low Bouguer anomaly at the north side of the fault. The maximum depth of the graben was estimated at around $2 \mathrm{~km}$ deep. A steep slope dipping to northward appeared at the south side of the graben and located at 0.5 to $1 \mathrm{~km}$ north of the active fault line drawn by the topographic discontinuity. The difference of resistivity structure was also detected at the same place. These results show that a buried fault is located at 0.5 to $1 \mathrm{~km}$ north of the active fault. A marked displacement of the basement was not detected by the gravity data nor the resistivity structure at the active fault. We interpreted that the fault seemed to have been active at the south wall of the graben before the Alluvium. The active place was moved to the south and the new activity has been started at the topographic discontinuity in recent time. These fault displacement suggests that extensional movement has been prevailing in this area during Quaternary.
\end{abstract}

Key words: Active fault, Graben, Gravity survey, Controlled source magnetotelluric method.

§1.はじめ

水縄断層は, 福岡県久留米市付近からほぼ東に延び, 浮羽町に達する延長約 $25 \mathrm{~km}$ の活断層系である [千田 (1981)].この断層は, 679 年に起こった筑紫地震の震源 断層と考えられており [松村 (1990)], 地形的にも明瞭 に追跡される [九州活構造研究会 (1989)].

九州北部と中部地域との境に位置するこのような東西 方向の断層系は, 東は別府湾加ら西は佐賀県伊万里市ま で連り,松山一伊万里構造線と呼ばれており, 水縄断首は その構造線の一部をなす断首系と見ることができる [千 田(1979)].この構造線に治って, 明瞭な低重力異常が 点々と見られる [駒沢・鎌田 (1985)].このような重力

\footnotetext{
* ₹812-81 福岡市東区箱崎 6-10-1
}

基盤の落ち込みによる地溝状の地質構造が活断層とどの ような関係にあるのかは明確ではない.

本研究では, 水縄断層の西部地域において, 重力測定, コントロールソースマグネトテルリク探査 (CSMT 探 查）および地表 $\gamma$ 線強度測定を行い, 負の重力異常から 推定される地溝状の構造の規模や水縄断層との位置関係 を調へ，断層周辺の地質構造の発達過程について考察し た.

\section{§2. 水縄断層の概要}

水縄断首は, 主として筑紫変成岩類および佐賀花岡岩 類からなる水縄山地の北麓をほぼ東西に走り, 山麓の扇 状地を変位させている 12 個の活断首からなるとされて いる [千田(1981)]. 断首の西端にある久留米市での遭 
跡調查により，679 年に発生した筑紫地震はこの断層の 活動による可能性が極めて高いと考えられている[松村 (1990)].九州北部地域では，ほぼ東西方向の松山一伊万 里構造線の存在が考えられており，それは別府北断層, 入実断層, 水縄断層, 都渡城一川久保断層等の東西系の 活断層により構成されていると考えられている[千田 (1992)]. 九州内でのこの構造線においては, 水縄断層東 部等一部で最近微小地震活動が比較的活発なところもあ るが, 全体的には地震の発生は少い [三浪 (1992)]. ま た，駒沢・鎌田 (1985) の九州中北部地域重力図による 之, 松山一伊万里構造線に沿って, 東西方向に延びた低重 力異常が点々と分布している. このような基盤の落ち込 みと考えられる低重力異常は, 松山一伊万里構造線を構 成する断層の活動に伴って形成された可能性が考えられ るが, 現在の活断層としての活動との関係についてはよ く分かっていない. 本研究ではこの点についての議論を 試みた。

\section{§3. 探查方法}

\section{1 重力測定}

重力探査は, シントレックス社製 CG3 型重力計を用 い, Fig. 1 に示した 140 地点において测定を行った. 各 測点での測定はサンプリング間隔 1 秒で 1 分間行った. ほとんどの測点は 1/2500 国土基本図に記されている標 高点を利用した。国土基本図の標高の表示は $0.1 \mathrm{~m}$ 単位 であるが実際は $1 \mathrm{~m}$ 程度の精度と考え, 重力の鉛直勾配 を $0.3 \mathrm{mgal} / \mathrm{m}$ 程度と考えると，それにより $0.3 \mathrm{mgal}$ 程度の誤差が生じる可能性はある. また, 重力計の精度 は $0.01 \mathrm{mgal}$ 程度であることを考虑すれば, 本探査の重 力値は $0.5 \mathrm{mgal}$ 程度の精度では得られたと考えられる. ドリフト補正は基点における閉合差を時間に応じて配分 した. 重力値は国道 210 号線上の 1 等水準点 2523 の国 土地理院による值を参照して決定した。潮汐補正は CG 3 型重力計標準装備の式である [LoNGMAN (1959)] によ り行った. 本地域の周囲には基盤岩類が分布しているの
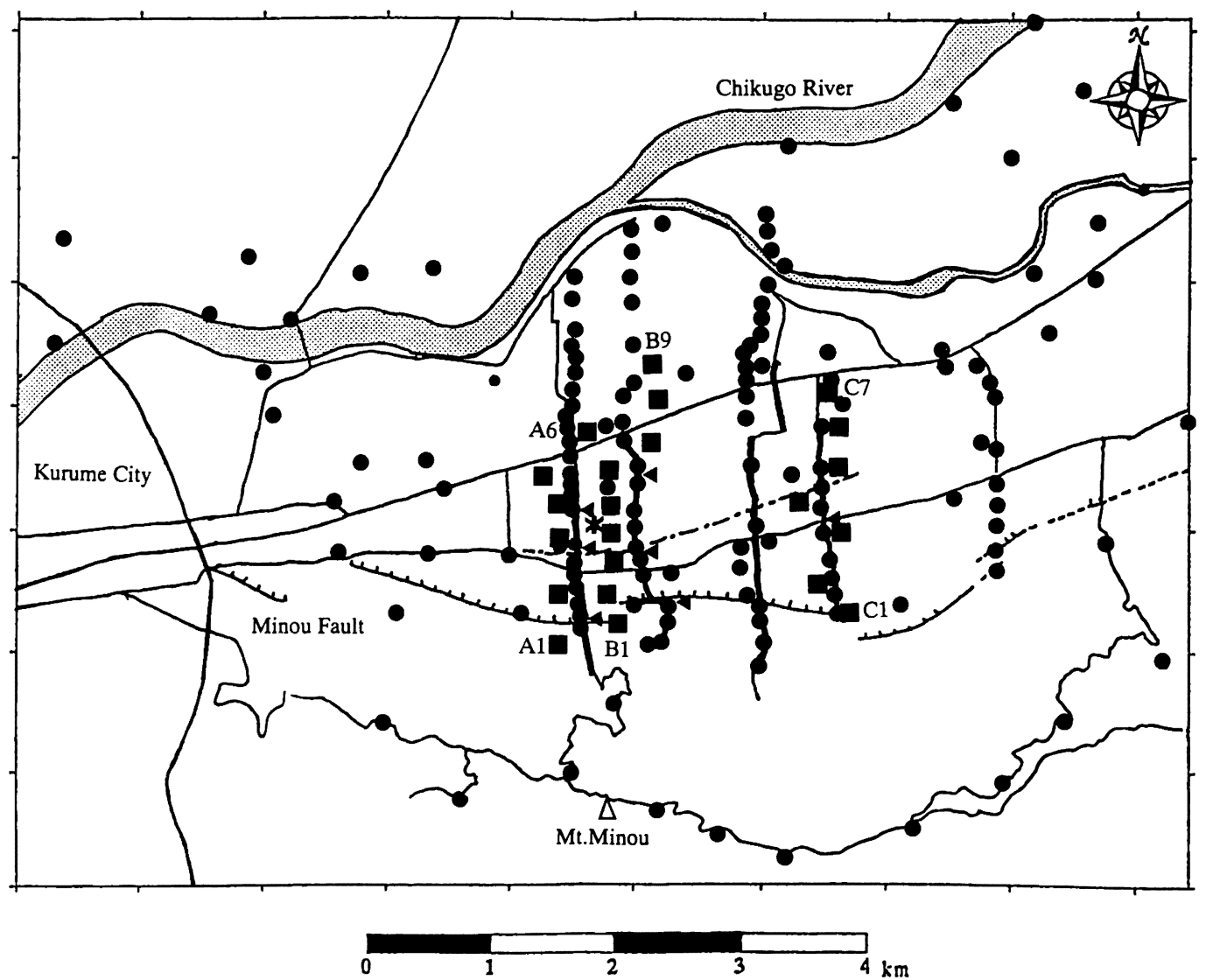

Fig. 1. Location of survey sites. - Gravity, $\mathbf{0}$ : CSMT survey, Bold lines show lines of $\gamma$-ray survey. The fault lines were drawn after CHIDA (1981). $\nabla$ : point of high $\gamma$-ray intensity, and $*$ : drilling site. A dash-dot-line denotes the fault inferred from this study. 
で, 地形補正，ブーゲー補正の際の仮定密度は $2.67 \mathrm{~g} /$ $\mathrm{cm}^{3}$ として行った.

\subsection{CSMT 探查}

CSMT 探査は水緡山地の北麓から筑後川の方向に断 層を横切る 3 測線に沿って測点をおいた. Fig. 1 に示す ように各測線上の 6 ないし 9 箇所に測点をおいた. 送信 線は測定地域から東に約 $5 \mathrm{~km}$ 離れた地域に南北方向に 約 $2 \mathrm{~km}$ の長さで設置した，送信線には $2 \sim 8 \mathrm{~A}$ の電流 を流した. 受信機は千葉電子製の複素位相検波方式 CSMT 探查機 [茂木・他 (1990)］を用いた. 測定した周 波数は 8700 4.2 Hz 間の 12 周波数である. 伝統的な CSMT 法では, 送信線と平行な方向の電場とそれに直 交する方向の磁場を湘定し，見掛比抵抗を求める.今回 の探査では, 測点が送信線より南側に片寄っているの で，必ずしあ測線に平行な方向の電場が卓越していると は限らないので, 電場, 磁場それぞれ南北, 東西方向の 成分を測定し，それぞれの組から得られる見掛比抵抗の 相乗平均値を測定値として使うことにした.このような
値を用いることで送信線の正面からはずれた測点でも妥 当な見掛比抵抗が得られると考えられる。测定した電 場, 磁場は, スミルノフの衰却検定 [岸根 (1977)] によ り異常値を除き，さらにそれらの間の相関が最大になる ように選択的にパワースペクトルのスタッキングを行っ た.

\section{3 地表 $\gamma$ 線強度測定}

地下深部のラドンガスは, 岩盤の割れ目に添って上昇 してきて，地表に濃集すると考えられている， $\gamma$ 線強度 湘定は，それが壊変していく際にその娘核種である， Bi (ウラン系列) や Tl (トリウム系列) から放射される $\gamma$ 線 を測定するあので，その強度はラドンが上昇して来る割 れ目の多い地点で大きいと考えられている.

今回の探査では，断層を横切るようにほぼ南北方向の 湘線沿いに $20 \mathrm{~m}$ 毎に $\gamma$ 線強度を測定した (Fig. 1). 測 定には日本原子力研究所製 E560A 型ポータブル $\gamma$ 線ス ペクトルメータを用いた。 センサーは 4 インチ径の NaI (Tl) 型シンチレーションセンサーを用いた. 各測点で
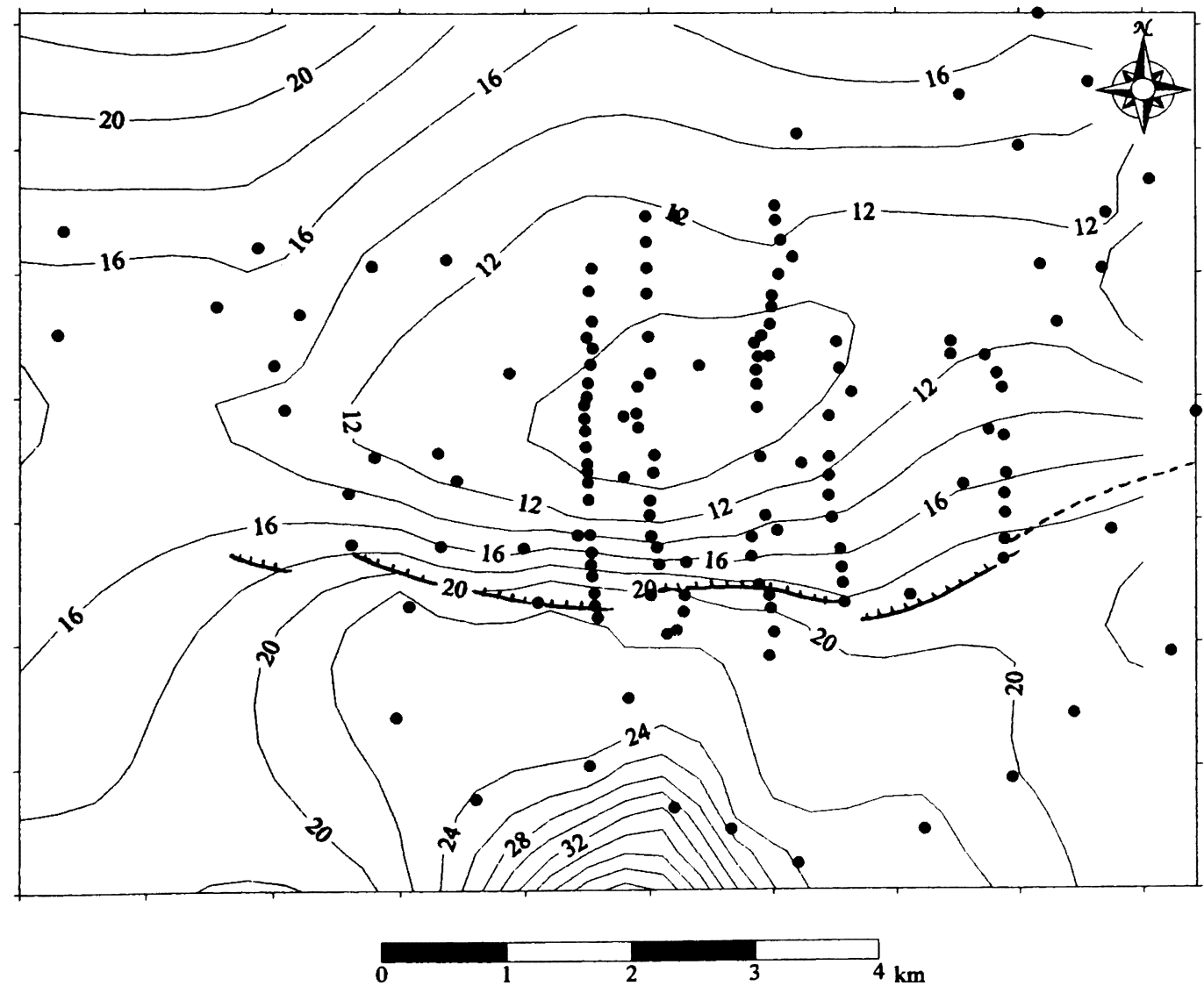

Fig. 2. Bouguer anomaly map. Density of the rock was assumed at $2.67 \mathrm{~g} / \mathrm{cm}^{3}$. Contour interval is 2 mgal. 
は, 原則として 5 分間測定し，その結果から，カリウム, ビスマス，タリゥムの正味のカウント数を茂木・神宮司 (1993)の方法により算出し, $\gamma$ 線強度の異常を抽出し た.

\section{§4. 探査結果}

\section{1 重力測定}

ブーゲー異常図を Fig. 2 に示す．この図には，千田 (1981)による水縄断首の地表での位置を示した。これに よると，断層の北側に大きな負の異常があり，それはほ ぼ東西方向に延びている．負異常の中心は断層の $2 \mathrm{~km}$ 位北にある.この結果を基に，基盤岩と表層の密度差を $0.5 \mathrm{~g} / \mathrm{cm}^{3}$ と仮定した時の，基盤深度を Fig. 3 に示す. この計算は CORDELL et al. (1992) による 3 次元イン パージョンプログラムを用いた. この結果を基に Fig. 3 の $\mathrm{A}-\mathrm{A}^{\prime}$ 断面に沿って基盤の分布を Fig. 4 に示す.

これらの結果によると, 水縄断層の北側には東西方向 の長さ約 $7 \mathrm{~km}$, 南北約 $2 \mathrm{~km}$ の地溝状構造が見られる. 基盤は山側から少しづつ深くなり，断層の北 $500 \mathrm{~m}$ 付
近からは急激に深くなり，最も深いところではその深度 は $1.5 \mathrm{~km}$ に達する，最す深い地点から北側では再び基 盤深度は徐々に浅くなり，断首から約 $3 \mathrm{~km}$ の筑後川付 近では深度は $1000 \mathrm{~m}$ より浅くなる.すなわち,この地 溝状構造は南側が急斜面であり北側は比較的ゆるい傾斜 を持つ非対称な形状である.このように水縄断層の北側 には，大きな基盤の落ち込みがあるが，基盤の傾斜が最 あ大きい所は, 現在見られる断層の北側 $500 \mathrm{~m} \sim 1 \mathrm{~km}$ の所であり, 地形上の断層の位置では基盤の大きな変位 は見られない，地溝状構造の南斜面では，傾きは最大約 60 度にもなり, 落差も大きいことから,この構造は単な る侵食等で生じたものではなく，断層の活動によるもの と考えられる.

Fig. 1 の*印で示した地点では，温泉水採取のための 掘削が行われた. その結果, 深度 $970 \mathrm{~m}$ において変成岩 類からなる基盤岩に到達した[久留米市（私信）］この 地点の重力探査から推定された基盤深度は約 $1000 \mathrm{~m}$ で あり，掘削結果とほぼ一致したことから，推定された構 造は妥当なむのであったと考えられる。
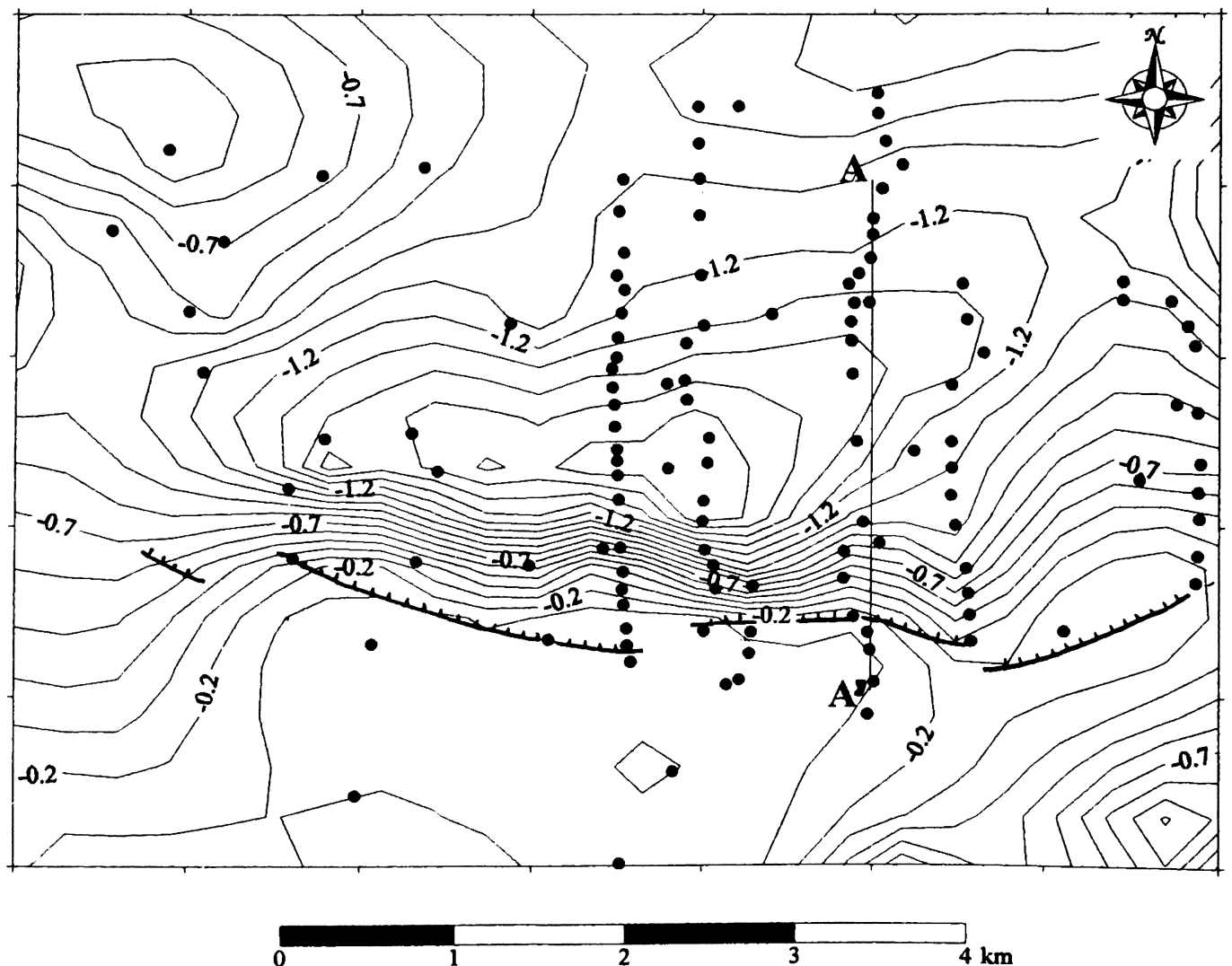

Fig. 3. Depth of the basement layer. Density difference between surface and basement was assumed to be $0.5 \mathrm{~g} / \mathrm{cm}^{3}$. Contour line interval is $0.1 \mathrm{~km}$ and the depth indicates at $\mathrm{km}$ in unit. 

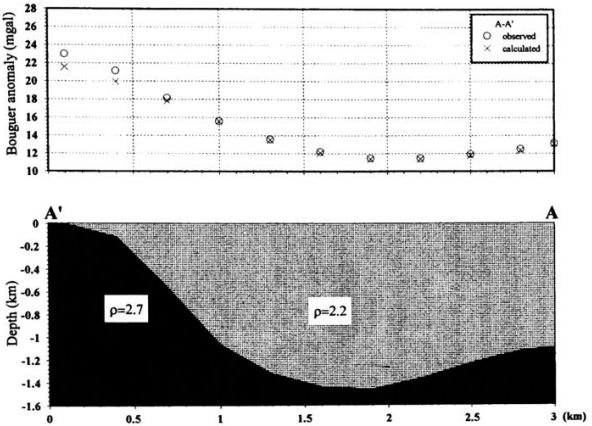

Fig. 4. Subsurface structure on the north-south cross section along $A-A^{\prime}$ line shown in Fig. 3.

\subsection{CSMT 探查}

探查の結果得られた見掛比抵抗と位相差を用いて、各 則線治いの断面について2次元インバージョンを行っ た結果得られた比抵抗権造を Fig. 5 に示した. 各測点で の測定値とインバージョン結果の比抵抗構造に対する見 期比抵抗値，位相差とを比較したA 測線の例をFig. 6 に示した. 2 次元インパージョンは，今回のデー夕は送 信電流によるニアフィールトの影䈉はないと考え, UCHIDA (1993)によるMT 法用の平滑化拘束付きイン パーションフログラムを使用した。

西側の A 測線の比抵抗構造では, 测点 A3 より南では $500 \Omega \mathrm{m}$ より大きい高比抵抗檴造が目立つが，それより 北側ではほとんど $100 \Omega \mathrm{m}$ 以下の地屇が分布している. この高比抵抗層が見られる境界はB 測線では測点 B2，

$\mathrm{C}$ 測線では測点 $\mathrm{C} 4$ と考えられる.これらの測点はいず れも現在知られている水縄断層の北側 $500 \mathrm{~m} \sim 1 \mathrm{~km}$ に あり, 重力探查で推定された基盤が急激に落ち込む地点 とほぼ一致する。従って、この高比抵抗構造汃基盤岩と 対応しているもの上考えることができる.

\section{3 地表 $r$ 線强度测定}

$\gamma$ 線強度の強い場所は地下にラトンガスの上昇が比較 的容易に行われるような割れ目が存在するあのと考えら れろ. $r$ 線强度が相対的に虽い地点を Fig. 1 にムで示し た.このような地点は，地形的に推定された水絙断屏付 近や重力探查やCSMT 探盁で推定された基盤岩梁度か
急激に变化する所に見られる.

\section{§5. 議碖}

Fig. 1 には，重力探査で基盤岩深度が急敨に变化する こと及びCSMT 探查で比抵抗構造が変化することから

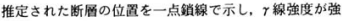
い地点をム印で合わせて示した，罒によると，地下構造 が大きく変化している地点は水縄断屭の北側 500 $1000 \mathrm{~m}$ の所にあり，明らかに地形で認識される断層の 位置とは異なる。その位宣では明眿な地形の変化は現在 は見られない，また，地形上の断層の位固では，重力や 比抵抗構造に大きな変化は見られないか、、線强度はを の上で強い所もある. 以上のことから，地形上の水綶断 層の位置では地下構造の受化は小さく、その大きな变化 はそれより北側の 500 $1000 \mathrm{~m}$ の所にあるすのと考え られる.この基盤滦度が急激に変化している地点では， 地形の変化は見られないことから, 主として䗰層の堆 棈完了以前に断屇として活動していたところではないか と推定される。 それ以降，断㒶活動は現在の地形上明摬 な断首の位固に移動したのではないかと考えられる. 地

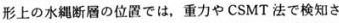
れるような大きな基盤の变位は見られず,この断層は活 動を開始してからあまり時間が経っていないので大きな 变位の䍗䖽を生じていないちのと考えられる，

水絈断層は，正断層的な様相を呈する所が多いとされ 

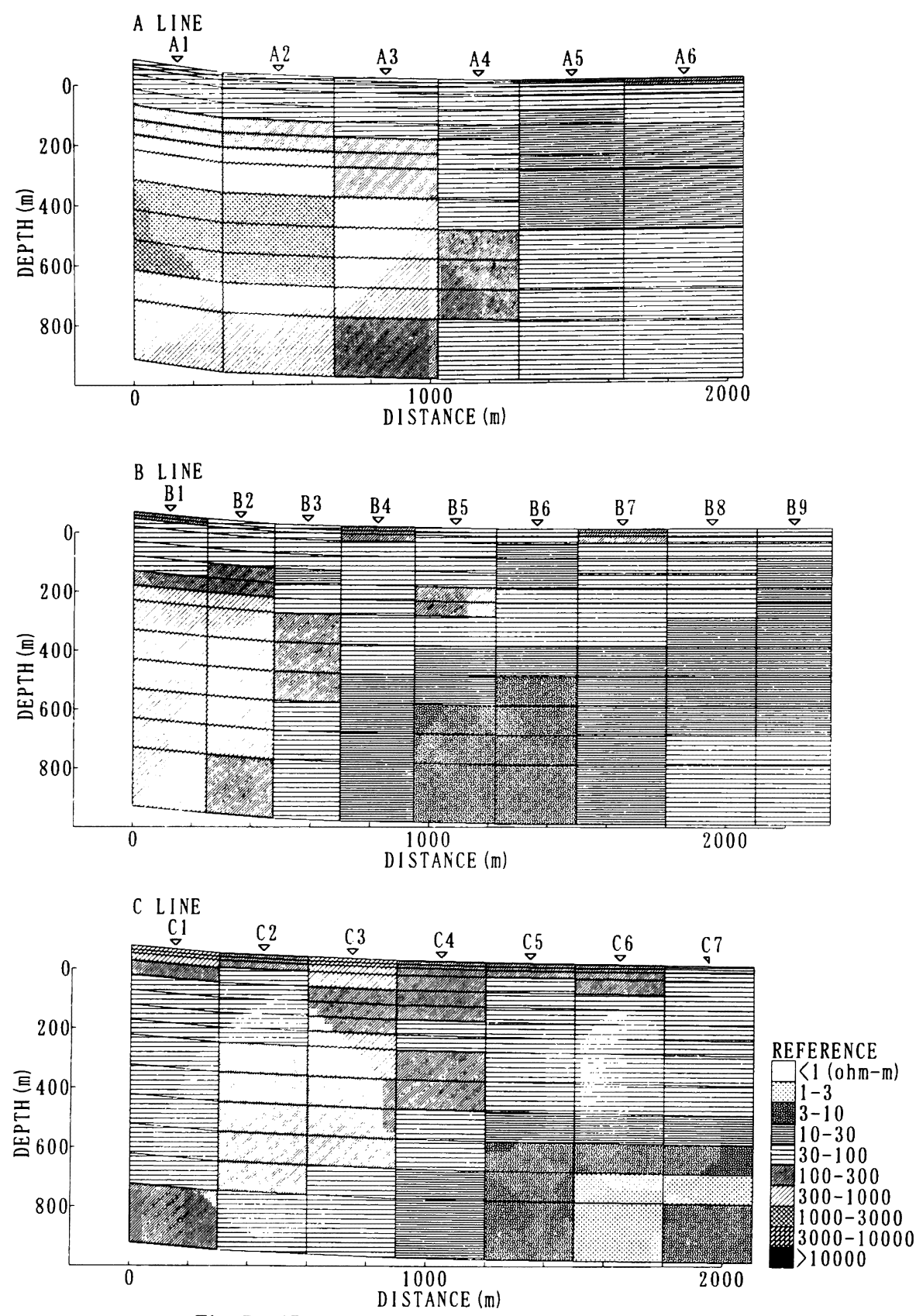

Fig. 5. 2D resistivity model along each survey line.

ているが，全体的な動きは不明確である [千田(1981)]. 木可 (1993) は，水縄断層を含む久留米一日出線の右横ず れの可能性を指摘している. 重力異常で見られた基盤の 断層は, 明らかに北傾斜であり正断層と考えられる. 水 䋲断首も正断層之考えれば，このことは正断層が山側に 後退したことを示唆している.このような正断首の移動 は，Fig. 7 に模式図を示したように，いわゆる imbri- cate listric fault [WERNICKE and BURCHFIEL (1982)] $の$ 発達過程と考えられ，現在は一番南側の断首による变位 のみが地形に現れていると考えられる。このような地質 構造は, 断首の走向之直交方向に延びるような地款変動 があるときに生じることが多い [GIBBS (1984)]. また, 駒沢・鎌田 (1985) による九州中部地域の重力構造によ ると, 地溝状構造の多くは南側は急斜面であるが北側は 

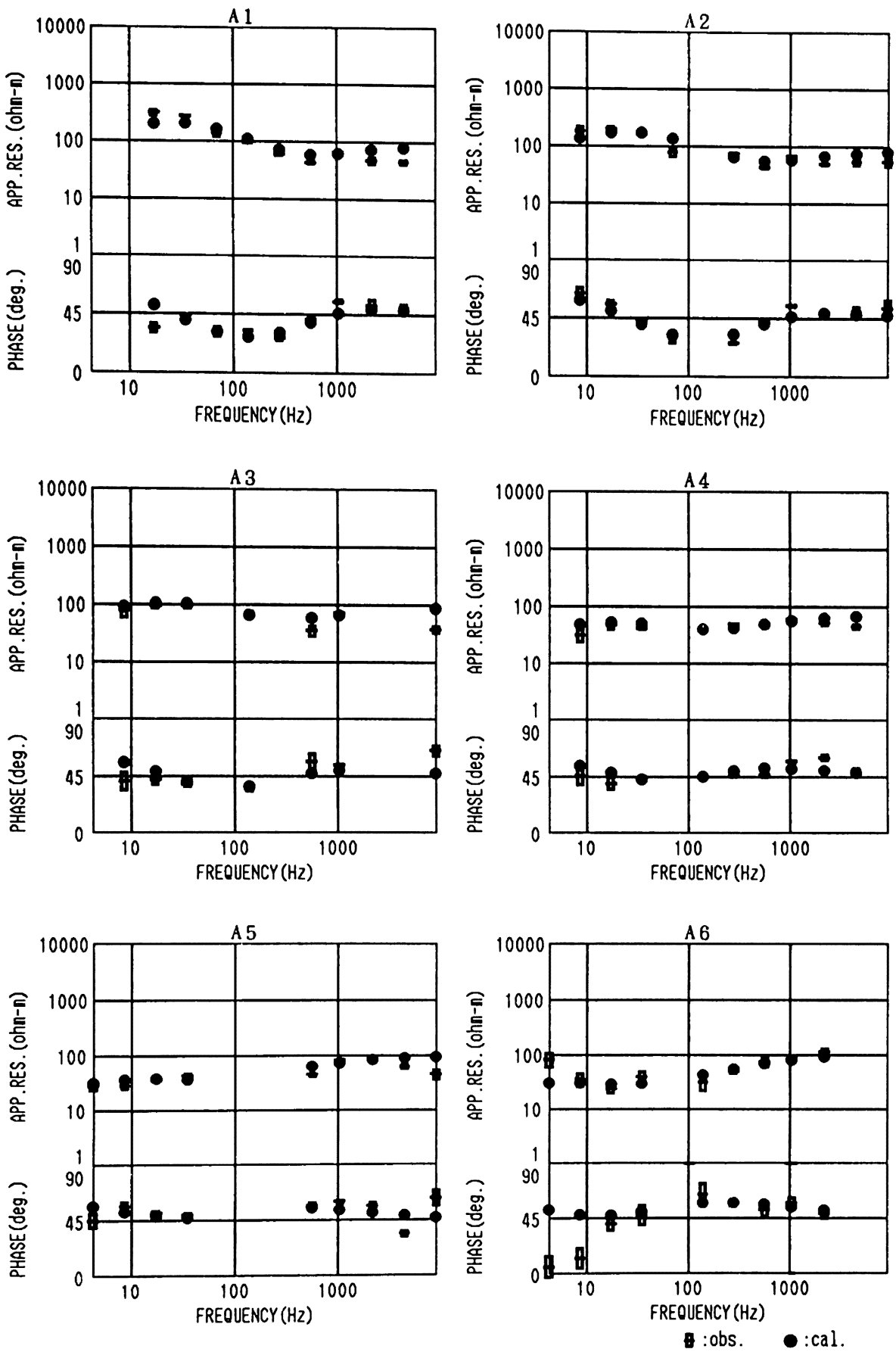

Fig. 6. Some examples of fit between observed and calculated data for the resistivity structure shown in Fig. 5. Observed values were denoted together with error bar.

ゆるい傾斜であることが多く，いわゆる半地溝状を呈す ることが多い，このような構造は，南北方向に地殼が伸 張しているときに生じることが多い，九州中部地域では 南北方向に拡大している可能性が指摘されており[千田
(1981)]，それに伴って正断層が発達していると考えら れている[池田(1979)]。このようなことを基にすると 水縄断層付近の断層の発達過程は, 南北方向の拡大に伴 い, 半地溝が南方へ拡大していくょうすを示しているも 


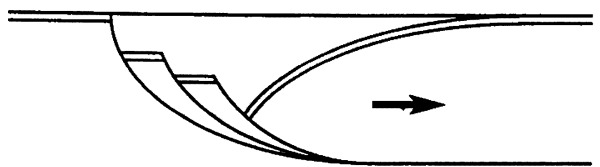

Fig. 7. Schematic figure of imbricate listric fault, modified from WERNICKE and BURCHFIEL (1982). The arrow in the upper block indicates direction of the displacement.

のと考えられる. 九州中部地域にはこれまで 7 個の地溝 (別府湾, 由布院, 崩平山, 万年山, 九重, 鞍岳, 雲仙) が認められてきたが [千田(1992)]，水縄断層地域にも 地溝帯が存在しており，今なお形成されつつあるとみな せる.

前述したように, 重力異常から推定された断層の地点 に温泉が掘削され，深度 $1000 \mathrm{~m}$ で温度 $51^{\circ} \mathrm{C}$ が記録さ れ，200 l/min の温泉水が湧出した。 このことは，断首 に沿って地下深部から温泉水が上昇して来ていることを 意味している. 比抵抗構造をみると，断層の北側に 10 $\Omega \mathrm{m}$ 以下の低比抵抗構造が見られる。これを温泉眝留層 と考えることもでき，それが地溝の中に広がっているす のと推定される. 実際この周辺には温泉がいくつか存在 することからあこのことは支持されるであろう.

\section{6. 結論}

本研究で得られた主な結果をまとめると以下の通りで ある.

(1) 水縄断層の北側に深さ $1.5 \mathrm{~km}$ に達する地溝状構 造が存在する。そその南側は正断層により区切られて いる。

(2) 水縄断層では大きな基盤の变位は見られないの で，この活断層は活動を開始してあまり時間が経っ ていないものと考えられる.

（3) 基盤の地溝状構造を作った断層の位置では地形的 な変位は見られないので，この断層の活動は少なく とも沖積層の堆皘完了以前に活動したものと考えら れる.

(4)水縄断層を正断首と考えれば, 地溝の南縁となる 断層は, 本研究で推定された断層の活動の後, さら に南側にある現在の水縄断層が活動の場となったも のと考えられる.このような正断首の後退は南北伸 張の応力場で生じたものと考えられる.

本研究により議論した地溝状の構造は, 水縄断層に 沿って, 東方にも続いており, それらの地域での研究む 今後必要であろう。また，この地溝を作った活動時期に
ついて議論を深めることは，九州北部地域と中部地域と のテクトニクスの特徵を考える上でも重要であろう.

\section{謝辟}

水縄断層での調查にあたっては，久留米市企画調整課 にご協力を頂いた。 また，九州大学理学部下山正一博士 および匿名の査読者には查読を通して原稿の不備な点の ご指摘や有益なコメントを頂いた，記して感謝の意を表 します.

\section{文献}

千田 昇, 1979, 中部九州の新期地殻変動一とくに第四 紀火山岩分布地域における活断層について一, 岩手大 学教育学部研究年報, 39, 37-75.

千田 昇, 1981 , 中部九州 - 水縄山地北簏の断層変位地 形, 岩手大学教育学部研究年報, 40, 67-78.

千田 昇, 1992, 中部九州の活断層一九州における中央 構造線の第四紀活動一, 地質学論集, No. 40, 39-51.

Cordell, L., J. D. Phillips and R. H. Godson, 1992, U.S. Geological Survey Potential-Field Geophysical Software Version 2.0, USGS Open File Rep. 92-18.

GiBBS, A. D., 1984, Structural evolution of extensional basin margins, J. Geol. Soc. London, 141, 609-620.

池田安隆, 1979, 大分県中部火山地域の活断層系, 地理 学評論, 52, 10-29.

木戸道男, 1993, 九重一別府地溝北西縁部の地質構造形 成史, 地質学論集, No. 41, 107-127.

岸根卓郎, 1977, 統計学, 養賢堂, 402 pp.

駒沢正夫・鎌田浩毅, 1985, 豊肥地域の重力基盤構造, 地質調查所報告, 264, 305-333.

九州活構造研究会, 1989, 九州の活構造, 東京大学出版 会, $553 \mathrm{pp}$.

Longman, I. M., 1959, Formulas for computing the tidal accerations due to the moon and the sun, J. Geophys. Res., 64, 2351-2355.

松村一良, 1990, “日本書紀” 天武七年条にみえる地震 と上津土畦跡について, 九州史学, 98, 1-23.

三浪俊夫, 1992 , 地球物理, 唐木田芳文・早坂祥三・長 谷義隆編, 日本の地質, 九州地方, 共立出版, 303310 .

茂木 透・楠 建一郎・鈴木浩一・川崎逸男・城森 明・東 義則, 1990, 複素位相検波方式 CSMT 探査 装置の開発，物理探査，43, 164-169.

茂木 透・神宮司元治, 1993, $\gamma$ 線スペクトルメータに よる活断層調査一 $\mathrm{NaI}(\mathrm{Tl})$ シンチレーション検出器に よるデータの自動評価解析一, 地震 2, 46, 1-8.

UCHIDA, T., 1993, Smooth 2-D inversion for magnetotelluric data based on statistical criterion ABIC, J. Geomag. Geoelect., 45, 841-858.

Wernicke, B. and B.C. Burchfiel, 1982, Modes of extensional tectonics, J. Structural Geol., 4, 105115. 